\title{
DISCRETE AND INTEGRATED APPROACH AND THE IMPLICATIONS ON LANGUAGE TEACHING LEARNING MANAGEMENT
}

\author{
Banun Havifah Cahyo Khosiyono \\ Universitas Sarjanawiyata Tamansiswa
}

\begin{abstract}
This paper describes discrete and integrated approach and the implication on language teaching learning management. Discrete approach emphasizes on the teaching and learning a language discretely, whereas integrated approach emphasizes on the whole language, namely speaking, writing, listening, reading, pronunciation, grammar, and vocabulary. In fact, both are interrelated since discrete learning is the basis for integrated learning. Both should be implemented in the teaching learning process in the classroom so that students are able to use the language well. Therefore, the curriculum or the syllabus, teaching materials, teachers' qualification, and classroom management should be prepared well.
\end{abstract}

Key words: reading classroom management, discrete learning, integrated learning

\section{INRODUCTION}

Language is very important for human life because serve many functions. Halliday (1973, Rahardi, 2009) mentions seven functions of language. They are instrumental function, regulation function, representational function, interactional function, personal function,heuristic function, and imaginative function. In order to have the capacity to use the language well, teacher should teach the language and the use of it to the students. based on this goal, teacher implements some methods and techniques to facilitate the students in mastering a language.

In the teaching learning process, teachers sometimes focus their teaching on speaking, writing, reading, listening, grammar, vocabulary, or pronunciation only. They emphasis on a single or discrete language skill or element. Then, when they think that the students have already mastered the language skill or elements, the teacher integrate those skills and elements into one so that students are able to use the language based on the real communication, that is based on the language functions.

Based on that, this paper will analyze the discrete approach and integrated approach in language teaching learning, including the characteristics, the implementation in the classroom, the assessment, and the implication on the teaching learning management.

\section{Perspective of Language Learning}

There are two differing perspectives of language learning dominating in English as a second language pedagogy, namely a product view and a process view (Smith, 1996:197). In theoretical models reflecting a product-oriented 
position, language is viewed primarily as an object to mastered. Two approaches adopting this perspective are audiolingual method and cognitive-code method. They focus on learners mastery and accurate use of discrete language items through a transmission model of teaching.

The word discrete in discrete of a linguistic unit means having clearly defined boundaries (Richards, Platt, and Weber, 1985: 84). Related to an approach, Rhalmi(2009) stated that language is seen as a sum of discrete blocks to be learned separately. It focuses on isolated language points that students must master before proceeding to a higher level. In discrete approach or segregatedskill approach, the mastery of discrete language skills such as reading and speaking is seen as the key to successful learning, and language learning is typically separate from content learning (Mohan, 1986 cited in Oxford, 2001). Skill segregation is reflected in traditional English as a second language/English as a foreign language programs that offer classes focusing on segregated language skills. In this case, teachers and administrators think it is logistically easier to present courses on writing divorced from speaking, or on listening isolated from reading. They may believe that it is instructionally impossible to concentrate on more than one skill at a time.

\section{Audiolingual Method}

Audiolingual method (Larsen-Freeman, 2000: 35) is an oral-based approach which drills students in the use of grammatical sentence patterns. Charles Fries (1945) led the way in applying principles from structural linguistics in developing the method. It was thought that the way to acquire the sentence patterns of the target language was through conditioning-helping learners to respond correctly to stimuli through shaping and reinforcement. Learners could overcome the habits of their native language and form the new habits required to be target language speakers. Further, he stated that grammar or structure was the starting point. The structure of the language was identified by its basic sentence pattern and grammatical structure. The language was taught by systematic attention to pronunciation and by intensive oral drilling of its basic sentence patterns. Pattern practice was a basic classroom technique. The basic patterns constitute the learner's task. According to him, students require drill, drill, and more drill, and only enough vocabulary to make such drills possible (Hockett, 1959 as cited in Richards and Rogers, 1986: 46).

\section{Cognitive-Code Method}

Cognitive-code approach or cognitive code learning refers to a theory of second language teaching and learning rooted in cognitivist psychology and structural applied linguistics developed in 1960s. The theory emphasises the centralrole of cognition in the conscious and explicit learning of the rules of a language as a code. The cognitive code approach to learning a second language sees it as a study of language as a complex system with the goal of gaining conscious control of the grammatical, lexical (vocabulary), and auditory patterns (Hinkel, 2011).Cognitive code learning theory was proposed and widely debated in the 1960s. Based on the foundation of linguistic theories and the findings of 
psycholinguistic research, such as John B. Carroll and Kenneth Chastain, advocate the cognitive code approach to the study of a second language as an alternative to the audio-lingual method prevalent at the time. Cognitive code learning theory (Chastain, 1971) proposes that learning a second language requires explicit instruction and a study of the language as a complex and rulegoverned system (Carroll, 1964). This approach took the view of a conscious study of the language structure as central and placed a great deal less emphasis on the development of a second language combination of skills. In the current perspective on second language learning, cognitive code theory is largely seen as an updated variety of the traditional grammar translation method, with an attendant goal of overcoming the shortfalls of the audiolingual approach.

Providing learners opportunities for a great deal of meaningful practice in a second language constitutes the central precept of cognitive code approach. The main emphasis on meaningful practice understood need for the learner first to understand the language rules and then apply them in the context of practical language use. Thus, explicit study of language rules, such as in grammar and vocabulary, was not only expected, but strongly encouraged. In the context of structural linguistics and behavioral psychology, cognitive code approach envisions practice to be meaningful when learners clearly understand and are able to apply language rules in practice. The essential difference between the audiolingual approach and the cognitive code approach is that in audiolingual approach, structural learning without an explanation and pattern drills are seen as leading to modifications in the learners' language bahaviour, while in cognitive code approach, students need to understand the linguistic rules before these can be implemented in practice. According to Carroll (1966) the theory attaches more importance to the learner's understanding of the structure of the foreign language than the facility in using that structure since it is believed that provided the student has a proper degree of cognitive control over the structure of the language, facility will develop automatically with use of language in meaningful situation.

Although people learned languages through audiolingual approach, one problem with it was the students' inability to readily transfer the habits they had mastered in the classroom to communicative use outside. The idea that learning a language meant forming a set of habits was challenged in the early 1960s.Chomsky argued that language acquisition could not possibly take place through habit formation since people create and understand utterances they have never heard before. He proposed that speakers have knowledge underlying abstract rules, which allow them to understand and create utterances; language must not be considered a product of habit formation, but rather of rule formation. Language acquisition must be a procedure whereby people use their own thinking processes or cognition to discover rules of the language they are acquiring (Larsen-Freeman, 2000:53).

The emphasis is on human cognition led to the establishment of the Cognitive Approach (Celce-Murcia, 1991 cited in Larsen-Freeman, 2000:53). Rather than simply being responsive to stimuli in the environment, learners were seen to be much more actively responsible for their own learning, engaged in formulating hypotheses in order to discover the rules of the target language. 
Errors were inevitable and were signs that learners were actively testing their hypotheses. In early 1970s, there was great interest in applying this new Cognitive Approach to language teaching and materials were developed with deductive and inductive grammar exercises. However, no language teaching method ever really developed directly from the Cognitive Approach; instead, a number of 'innovative methods' emerged.

Silent Way proposed by Gattegno which did not stem directly from CA shared a certain principle with it, for example one of the its basic principles is 'Teaching should be subordinated to learning'. In other words, Gattegno believed that to teach means to serve the learning process rather than to dominate it. This principle is in keeping with the active search for rules ascribed to the learner in the Cognitive Approach. Learning is a process which is initiated by oneself by mobilizing inner sources (perception, awareness, cognition, imagination, intuition, and creativity) to meet the challenge at hand (ibid, 54).

\section{Assessment of Discre-Point Testing Approach}

Evaluation is discrete point in nature, that is, each question on the test focuses on only one point of the language at a time. Students might be asked to distinguish between words in a minimal pair or to supply appropriate verb form in a sentence.

Dewi and Natiti (2012) state that the strength of discrete point testing approach are the test of this approach can cover a wide range of scope of materials to be put in the tests; the test allows quantification on the students' responses; and in the term of scoring, the test is also reliable because of its objectivity; the scoring is efficient, even it can be perform by machine. The weaknesses are constructing discrete point test items is potentially energy and time consuming; the test do not include social context where verbal communication normally take place; success in doing the test is not readily inferable to the ability of the test taker to communicate in real life circumstances. Besides, the weaknesses (Aslam, 1992: 102) are the tests failed to reflect actual language use; do not measure skills of language processing or use adequately; evaluation of discrete point test. A discrete point test like that of twenty lexical items for vocabulary cannot evaluate knowledge of language since language consists of more than just knowing vocabulary. Language proficiency is more than just the sum of the discrete elements. Besides, discrete point tests were only achievement tests; in these tests, only a part of communicative process is tested. In a test of grammar, only part of the whole process of language usage is tested. These tests ignore the communicative content completely. The problem was that there was a wide gap between the way they tested language and the way one operates with language.; whatever language was tested was devoid of a real life context which is the context for actual use.; it is impossible to compile a representative sample from all elements of a language to use for a test of this kind.; it is impossible to assess the contributions of individual elements of language to language as a whole; and amultiple choice test which is a discrete point test, is a difficult test since it needs substantial skill on the part of the teacher. 


\section{Integrated Approach}

In language teaching, integrated approach means the teaching of the language skills of reading, writing, listening, and speaking, in conjuction with each other, as when a lesson involves activities that relate listening and speaking to reading and writing (Richards, Platt, and Weber, 1988: 144). Further, Hinkel (1999 cited in Kecira and Shllaku, 2014) writes that in common perspectives on contemporary language curricula, teaching reading is typically connected to instruction on writing and vocabulary, teaching writing can be easily tied to reading and grammar, and speaking skills readily lend themselves to teaching listening, pronunciation, and cross-cultural pragmatics. And, in the age of globalization, pragmatic objectives of language learning place an increased value on integrated and dynamic multiskilled instructional models with focus on meaningful communication and the development of learners' communicative competence.

On the other hand, underlying the process-oriented models, there is an assumption that language is an activity, not a product, and emphasis is placed on the use of language for communicative purposes. This perspective underlies communicative language teaching approach (Littlewood, 1981 and Savignon, 1983 cited in Smith, 1996) and task-based teaching (Long, 1985 cited in Smith, 1996). These process-oriented teaching approaches emphasize student-centered classrooms in which teachers are facilitators and activities which focus on communication of meaning rather than accuracy and form.

Oxford (2001) as cited by Aponte-de-Hanna (2015)explains that discrete teaching is one of English as a second language (ESL) approaches that is not conducive to communicative competence. In an adult ESL context, where the aim is to provide learners with authentic experiences, a discrete approach is counterproductive. Although it might work well for students seeking to hone a particular skill, or for programs offering skill training, it is an antiquated approach. In real life, people interchange skills to interact, socialize, and set goals.

There are some elements that support the success of English teaching learning process,such as the characteristics of the teacher, the learner, the setting, and the relevant languages (English and the native languages of the learners and the teacher). All of them must be interwoven in positive ways. For example, the instructor's teaching style must address the learning style of the learner, the learner must be motivated, and the setting must provide resources and values that strongly support the teaching of the language.

There are other important elements, one of the most crucial one consists of the four primary skills of listening, reading, speaking, and writing. This also includes associated or related skills such as knowledge ofvocabulary, spelling, pronunciation, syntax, meaning, and usage. The skill leads to optimal ESL/EFL communication when they are interwoven during instruction. This is known as the integrated-skill approach (Oxford, 2001).

Fortunately, in many instances where an ESL or EFL course is labeled by a single skill, the segregation of language skills might be only partial or even illusory. If the teacher is creative, a course bearing a discrete-skill title might 
actually involve multiple, integrated skills. For example, in a course on intermediate reading, the teacher probably gives all of the directions orally in English, thus causing students to use their listening ability to understand the assignment. In this course, students might discuss their readings, thus employing speaking and listening skills and certain associated skills, such as pronunciation, syntax, and social usage. Students might be asked to summarize or analyze readings in written form, thus activating their writing skills. In a real sense, then, some courses that are labeled according to one specific skill might actually reflect an integrated-skill approach after all.

The same can be said for ESL/EFL textbooks. A particular series might highlight certain skills in one book or another, but all the language skills might nevertheless be present in the tasks in each book. In this way, students have the benefit of practicing all the language skills in an integrated, natural, communicative way, even if one skill is the main focus of a given volume.

\section{Types of Integrated-Skill Instruction}

Two types of integrated-skill instruction are content-based language instruction and task-based instruction. The first of these emphasizes learning content through language, while the second stresses doing tasks that require communicative language use. Both of these benefit from a diverse range of materials, textbooks, and technologies for the ESL or EFL classroom.

\section{Content-Based Instruction}

In content-based instruction, students practice all the language skills in a highly integrated, communicative fashion while learning content such as science, mathematics, and social studies. Content-based language instruction is valuable at all levels of proficiency, but the nature of the content might differ by proficiency level. For beginners, the content often involves basic social and interpersonal communication skills, but past the beginning level, the content can become increasingly academic and complex. The Cognitive Academic Language Learning Approach (CALLA), created by Chamot and O'Malley (1994) shows how language learning strategies can be integrated into the simultaneous learning of content and language.

At least three general models of content-based language instruction exist: theme-based, adjunct, and sheltered (Scarcella\& Oxford, 1992). The theme-based model integrates the language skills into the study of a theme (e.g., urban violence, cross-cultural differences in marriage practices, natural wonders of the world, or a broad topic such as change). The theme must be very interesting to students and must allow a wide variety of language skills to be practiced, always in the service of communicating about the theme. This is the most useful and widespread form of content-based instruction today, and it is found in many innovative ESL and EFL textbooks. In the adjunct model, language and content courses are taught separately but are carefully coordinated. In the sheltered model, the subject matter is taught in simplified English tailored to students' English proficiency level. 
There are numerous practical features of CBI (Brinton, Snow, \&Wesche, 1989 cited by Stoller in Richards and Renandya, 2002: 108):

In a content-based approach, the activities of the language class are specific to the subject matter being taught, and are geared to stimulate students to think and learn through the use of the TL. Such an approach lends itself quite naturally to the integrated teaching of the four traditional language skills. For example, it employs authentic reading materials which require students not only to understand information but to interpret and evaluate it as well. It provides a forum in which studentscan respond orally to reading and lecture materials. It recognizes that academic writing follows from listening and reading, and thus requires students to synthesize facts and ideas from multiple sources as preparation for writing. In this approach, students are exposed to study skills and learn a variety of language skills which prepare them for the range of academic tasks they will encounter.

The quotation shows that CBI offers ideal conditions for language learning. There are four findings from research in educational and cognitive psychology that emphasize the benefits of content-based instruction (Stoller in Richards and Renandya, 2002: 2008): 1) thematically organized materials, typical of contentbased classrooms, are easier to remember and learn (Singer, 1990); 2) the , characteristic of well-presentation of coherent and meaningful information, characteristic of well-organized content-based curricula, leads to deeper processing, and better learning (Anderson, 1990); 3) there is a relationship between student motivation and student interest - common outcomes of contentbased classes - and a student's ability to process challenging materials, recall information, and elaborate (Alexander, Kulikowich, \& Jetton, 1994); and 4) expertise in a topic develops when learners reinvest their knowledge in a sequence of progressively more complex tasks (Bereiter\&Scardamalia, 1993), feasible in content-based classrooms and usually absent from traditional language classrooms because of the narrow focus on language rules or limited time on superficially developed and disperatetopics.

Content-based instruction allows for natural integration of sound languageteaching practices such as alternative means of assesment, apprenticeship learning, cooperative learning, integrated-skills instruction, project work, scaffolding, and strategy training.Some language professionals equate project work with in-class group work, cooperative learning, or more elaborate task-based activities.Project-based learning should be viewed as a versatile vehicle for fully integrated language and content learning, making it a viable option for language educators working in a variety of instructional setting including general English, English for academic purpose (EAP), English for specific purpose (ESP), and English for occupational /vocational/professional purposes, in addition to preservice and in-service teacher training. Project work is viewed not as a replacement for other teaching methods, but rather as an approach to learning which complements mainstream methods and which can be used with almost all levels, ages, and abilities of students (Haines, 1989 cited by Stoller in Richards and Renandya, 2002: 109).In classrooms where a commitment has been made to content learning as well as language learning (i.e. content-based classroom), 
project work is particularly effective because it represents a natural extention of what is already taking place in class.

\section{Task-Based Instruction}

A task is an activity which learners carry out using their available language resources and leading to a real outcome (Richards and Renandya, 2002: 94). Examples of tasks are playing a game, solving a problem, or sharing and comparing experiences. In carrying out tasks, they take part in such processes as negotiation of meaning, paraphrase, and experimentation. Further, Sekhan (1998 cited by Beglar and Hunt in Richards and Renandya, 2002: 100) proposed that a task is an activity in which meaning is primary, there is a communication problem to solve, and the task is closely related to real-world activities.

In task-based instruction, students participate in communicative tasks in English. Tasks are defined as activities that can stand alone as fundamental units and that require comprehending, producing, manipulating, or interacting in authentic language while attention is principally paid to meaning rather than form (Nunan, 1989).

The task-based model is beginning to influence the measurement of learning strategies, not just the teaching of ESL and EFL. In task-based instruction, basic pair work and group work are often used to increase student interaction and collaboration. For instance, students work together to write and edit a class newspaper, develop a television commercial, enact scenes from a play, or take part in other joint tasks. More structured cooperative learning formats can also be used in task-based instruction. Task-based instruction is relevant to all levels of language proficiency, but the nature of the task varies from one level to the other. Tasks become increasingly complex at higher proficiency levels. For instance, beginners might be asked to introduce each other and share one item of information about each other. More advanced students might do more intricate and demanding tasks, such as taking a public opinion poll at school, the university, or a shopping mall.

\section{Assessment of Integrative Approach}

Dewi and Natiti (2012) state that the strengths of integrative approach are the approach to meaning and the total communicative effect of discourse will be very useful for pupils in testing; this approach can view pupils' proficiency with a global view; and the strength of the test such as dictation, writing, and cloze test is that relatively cheap and easy to make. The weaknesses are even if measuring integrated skills are better but sometimes teacher should consider the importance of measuring skills based on particular need, such as writing only, speaking only; and the scoring is not efficient and not reliable.

\section{The Implication on the Language Teaching Learning Management}

As described above that in implementing integrated approach, teacher can have content-based learning and task-based learning. Therefore, there are some points to considered in teaching learning management as follows. 
The syllabus must be communicative syllabus, such as notional-functional, situational, lexical, task-based, and procedural syllabi. Finney (in Richards and Renandya, 2002: 65) proposes an integrated, mixed-focus model for curriculum design, within which there is flexibility to respond to the changing needs of learners and recognition of learners as active participants in language learning process.

The teaching materials should vary since they serve as the basis for much of the language input learners receive and the language practice that occurs in the classroom. These may take the form of printed materials such as books, workbooks, worksheets, or readers; nonprint materials such as cassette or audio materials, videos, or computer-based materials; and materials that comprise both print and nonprintcourses such as self-access materials and materials on the internet. Other instructional materials, such as magazines, newspaper, and TV materials may also play a role in the curriculum.

The 21st century, teachers as aducators should have some qualification (Madya, 2013: 114) such as navigator, adaptor, communicator, learner, visionary, professional, leader, role model, collaborator, risk taker, and coach and mentor.There are also some consideration in planning for effective classroom management, such as getting to know the students, creating learning environment, establishing classroom rules and procedures, getting students cooperation, managing classroom activities, finding effective management style, and managing discipline.

\section{CONCLUSION AND SUGGESTION}

From the above description, it is clear that discrete approach and integrated approach complement to each other. Discrete learning which emphasizes on the discrete or single language skill or element becomes the basic for integrated learning. In order to be able to write, students should have sufficient vocabulary to master and understand the sentence structure or grammar rules. When students read, they have to know the meaning of the words and the structure of the sentences as well. In order to speak, students need to master sufficient vocabulary, pronounce, and stress the words precisely. Sometimes, students listen to the instruction of the teacher, then write it down, then read the written instruction, and asking question related to the instruction. In brief, discrete learning enables students to master a single language skill or element and integrated learning enables them to use the language in real or authentic communication.

To support the achievement of the instructional goal, the curriculum and the syllabi should be designed well. The teaching materials need to be prepared in advance. The teachers as one of the keys elements of the success of teaching learning in class should meet the criteria of the $2^{\text {st }}$ century educators. And, the classroom should be managed well so that the teaching learning process can run well.

\section{REFERENCES}


Aponte-de-Hanna, C. (2015). A discrete approach to teaching ESL - what does it mean?Accessed on 14 March 2016 from http://blog.teslontario.org/adiscrete-approach-to-teaching-esl-what-does-it-mean/.

Aslam, R. (1992_. Aspect of language teaching. New Delhi: Nothern Book Centre.

Beglar, David \&Hunt, A. Implementing task-based language teaching in Richards and Renandya. (2002). Methodology in language teaching: An anthology of current practice.

Crawford, J. (2002)The role of materials in the language classroom: Finding the balance. In Richards and Renandya. Methodology in language teaching: An anthology of current practice.

Dewi, R.K. \&Natiti, N.S. (2012). Approaches in language testing. Accessed on 14 March 2016 from https://thejoyoflanguageassessment.wordpress.com/2012/12/19/approachesin-language-testing-2/

Finney, D. (2002).The ELT curriculum: A flexible model for a changing world in Richards and Renandya. Methodology in language teaching: An anthology of current practice.

Halliday, M.A.K. (1973). Explorations in the Functions of Language. London: EdwardArnold.

Hinkel, E.(2011). Encyclopedia of the science of learning.Springer science, Business Media, LLC.

Kecira, R \&Shilaku, A. (2014).Skills segregation versus skills integration in FLT in ICRAE Conference - Paper proceedings, ISSN: 2308-0825.

Larsen-Freeman, D. (2000). Techniques and principles in language learning.Oxford University Press.

Littlewood, W. (1981).Communicative language teaching: An introduction. New York: Cambridge University Press.

Madya, S. (2013).Metodologipengajaranbahasadari era prametodesampai era pascametode. Yogyakarta: UNY Press.

Oxford, R. (2001). Integrated skills in the ESL/EFL classroom. Eric Digest. Accessed on 14 March 2016 from http://www.ericdigests.org/20022/esl.htm.

Rahardi, R. K. (2009). Bahasa Indonesia untukperguruantinggi. Jakarta: Erlangga

Rhalmi, M. (2009).Language testing. Accessed on 14 March 2016 from http://www.myenglishpages.com/blog/language-testing/ 
Richards, J. C. and Willy A. R. (2001).Methodology in language teaching: An anthology of current practice. New York: Cambridge University Press.

Richards, J.C. and Theodore S. R. (1986).Approaches and methods in language teaching. Cambridge: Cambridge University Press.

Richards, J., Plait, J. \& Weber, H. (1985).Longman dictionary of applied linguistics. Longman

Smith, D. B. (1996).Teacher Decision Making in the Adult ESL Classroomin Teacher Learning in language Teaching, edited by Donald A. Freeman and J. C. Richards. Cambridge: Cambridge University Press.

Stoller, F. L. (2002).Project Work: A means to promote language and content in Richards and Renandya. Methodology in language teaching: An anthology of current practice.

Tillitt, B. \&Bruder, M.N. (1985).Speaking naturally: Communication skills in American English. New York: Cambridge University Press. 